\title{
Particle Pollution and Urban Forests: An Estimation of Particle Density on Leaves of Urban Plants Using Scanning Electron Microscopy
}

\author{
Samira Muhammad ${ }^{1}$, Karen Wuyts², Karolien De Wael ${ }^{3}$, Roeland Samson ${ }^{4}$ \\ ${ }^{1,2,4}$ Laboratory of Environmental and Urban Ecology, Department of Bioscience Engineering, University of Antwerp, \\ Groenenborgerlaan 171, 2020 Antwerp Belgium \\ ${ }^{3}$ AXES Research Group, Department of Chemistry, University of Antwerp, \\ Groenenborgerlaan 171, 2020 Antwerp Belgium \\ samira.muhammad@uantwerpen.be,karen.wuyts@uantwerpen.be, \\ karolien.dewael@uantwerpen.be,roeland.samson@uantwerpen.be
}

\begin{abstract}
Leaves of sixteen urban plant species were examined for particle density in June and September 2016 using scanning electron microscopy (SEM). The particle density was estimated by particle size fraction and leaf sides. The total particle density for coarse and fine fraction on both the abaxial and the adaxial leaf side ranged between 202 to 10,981 particles $\mathrm{mm}^{-2}$ in June and 30 to 1,984 particles $\mathrm{mm}^{-2}$ in September. To determine the repeatability of the SEM methodology for particle density assessment, repeated measurements were performed at long time-intervals in different SEM sessions and on short time-intervals within the same SEM session. The withinsession successive repeated measurements elucidated that features constructing the topography of a leaf surface frequently contributed towards the edge enhancement effect, resulting in exaggerated particle counts. Besides, the mechanical drift and charging effects contributed to the disparity in particle densities. The results from our study enable us to suggest that SEM will continue to be a useful approach for determining the particle shape, size, elemental composition, and density of the deposited particles. However, disparities in particle densities can occur due to inaccurate particle recognition. We recommend that within-session successive repeated measurements $(\sim \mathrm{n} \geq 5)$ need to be performed to remove measurement uncertainties and obtain reliable quantitative data of particle counts using SEM.
\end{abstract}

Keywords: Particulate matter, Leaf micro-morphology, Scanning Electron Microscopy (SEM), Particle recognition, Edge enhancement, Charging, Drifting

\section{Introduction}

The occurrence of particulate matter (PM) is typical in the event of incomplete combustion of fuel in car engines, road surface erosion, tire wear, and industrial activities [1]. Thus, urban areas require sustainable solutions to reduce PM pollution. Urban plants can reduce atmospheric PM by capturing them on their leaf surfaces or directing them to the ground during rainfall $[2,3,4,5,6]$. However, not all urban plants are equally effective in capturing PM on their leaf surfaces [3, 4, 5, 7]. The differences in particle load collected on leaf surfaces depends on the leaf micro-morphology such as trichomes, epicuticular waxes, and leaf wettability $[2,8,9,10]$.

PM adsorbed on leaf surfaces is frequently estimated using gravimetric analyses [3]. This relatively easy method provides distribution of surface and in-wax accumulated PM by mass and size fraction. However, water-soluble ions which account for $45 \%$ of the total PM mass in some samples might not be accounted for [11]. Hence, only the insoluble PM fraction is quantified, which may increase the likelihood of an under-estimation of the total adsorbed PM. Besides, the dissolved organic particle constituents could be dissolved in chloroform but remain with the removed wax layer after evaporation of chloroform, possibly resulting in higher wax amounts. Lately, environmental magnetic analyses [12] has been frequently used to measure the ferro-magnetic and metal component of PM. Next to magnetic susceptibility, Saturation Isothermal Remanent Magnetization (SIRM) a proxy for the accumulation of traffic and industry induced particles and has proven to be rapid, affordable and a good indicator for leaf surface accumulated and leaf in-wax immobilized particles [12, 13]. Nonetheless, leaf SIRM neither quantifies the number of accumulated particles nor does it distinguishes between the size fractions of accumulated particles. Alternatively, scanning electron microscopy (SEM) enables the estimation of particle density, its size fraction and elemental composition [15]. The SEM imaging involves the detection of secondary electrons (SE) which are sample derived-electrons generated from the interaction of the primary electron beam with the top 1-10 $\mathrm{nm}$ 
of the sample surface $[15,16]$ while, the backscattered electrons (BSE) are beam electrons which have been scattered deeper within the sample [17]. The BSE image provides an atomic number map of the investigated specimen [15, 18].

Scanning electron microscopy is conventionally used in the field of industrial and manufacturing research for its qualitative and quantitative applications. Over the last few decades, data concerning plant surfaces, i.e., characterization of epidermal surfaces, trichomes, and epicuticular wax structures have been published [19-25]. Besides, the use of SEM in the assessment of particle density (the number of particles deposited per unit area) and size fraction of particles deposited on leaves have been regularly reported [26-28]. To date, most studies using SEM for examining the particle density did so on leaves of evergreen plant species with sparse to no leaf trichomes [27-29], and a rather simple leaf micro-morphology [26] but see the study by Weerakkody et al.[30]. However, very little is known whether a more complex leaf micro-morphology would allow proper particle density measurements, and whether these results can be replicated.

The specific objectives of this study were to (a) estimate the density of coarse and fine-particles on leaves of perennial deciduous and evergreen plant species $(n=16)$ with complex leaf micro-morphology, (b) identify the effect of leaf micromorphology, leaf side, exposure time and particle size fraction on particle density and (c) test the repeatability and identify limitations of the methodology by performing time-interval and within-session successive repeated measurements of particle density on leaves of a subset of plant species $(n=4, n=5)$ respectively. We hypothesize that (i) leaf samples with pronounced leaf micro-morphology, i.e. high trichomes density, convex epidermal cells forming deep grooves between cells, show an increased count values in all particle size fractions.

\section{Materials and Methods}

\subsection{Experimental Set-Up and Plant Material}

The study was conducted as a common-garden experiment located at $51^{\circ} 10^{\prime} 46.0^{\prime \prime} \mathrm{N}, 4^{\circ} 25^{\prime} 0.02^{\prime \prime} \mathrm{E}$ on the premises of the University of Antwerp (Antwerp, Belgium). All plant species and their respective replicates $(n=5)$ were bought from one nursery (Houtmeyers in Eindhout - Laakdal, Belgium) and planted in a 15L pot with organic potting soil (Peltracom $\mathrm{NV}$, Belgium) infused with $150 \mathrm{~g}$ of Multicote 8, controlled release fertilizer (Haifa Group N: P: K of 15:7:15 with MgO and trace elements). All plants were generously watered and left to grow in a spatially uniform environment with similar atmospheric and climatic conditions. During the sampling period, the monthly mean minimum and maximum $\mathrm{PM}_{10}$ concentrations were 10.7 and $49.9 \mu \mathrm{g} \mathrm{m}^{-3}$ respectively. The monthly mean minimum and maximum $\mathrm{PM}_{2.5}$ concentrations were 4.4 and $31.7 \mu \mathrm{g} \mathrm{m}^{-3}$ respectively. The monthly mean minimum and maximum temperature was 12 and $23{ }^{\circ} \mathrm{C}$ respectively. The monthly mean minimum and maximum wind speed were 1 and $6 \mathrm{~m} \mathrm{~s}^{-1}$ respectively. The monthly mean minimum and maximum relative humidity $(\mathrm{RH})$ was 47 and $92 \%$ respectively. The atmospheric data were obtained from station Antwerpen Luchtbal (42R817) whereas the meteorological data were obtained from Antwerpen Luchtbal (42M802), operated by Flanders Environment Agency (VMM). The investigated plant species $(n=16)$ were selected for the following reasons, (a) leaves of investigated plant species except for Rhododendron had pronounced complex leaf micro-morphology (Table 1), (i.e., sparse to dense trichomes, epicuticular wax crystals, pronounced venation, convex epidermal cells which form deep grooves between cells and raised stomata) and (b) leaves of Rhododendron were used as reference plant species as they represent a simple leaf micro-morphology due to the absence of trichomes, epicuticular wax structure of mostly thin film and some platelets, marginally raised stomata and no deep grooves formed between epidermal cells.

Table 1 The description of leaf micro-morphology for a subset of investigated plant species $(\mathrm{n}=16)$ belonging to respective functional plant types. The trichome and stomatal density $\left(\mathrm{mm}^{-2}\right)$ were reported previously (Muhammad et al. 2019) and epicuticular wax structure (EWS) were reported by (Muhammad et al. 2020). The missing values are indicated by "-."

\begin{tabular}{|c|c|c|c|c|c|}
\hline Plant type & Species & Trichomes & Stomata & EWS & Description of leaf micro-morphology \\
\hline \multirow{4}{*}{$\begin{array}{l}\text { Deciduous } \\
\text { broadleaf } \\
\text { trees }\end{array}$} & $\begin{array}{l}\text { Catalpa } \\
\text { bignonioides }\end{array}$ & Yes (5.29) & 422.1 & Thin film & $\begin{array}{l}\text { Presence of raised stomata and convex epidermal cells } \\
\text { form deep grooves between cells. (Fig. 1) }\end{array}$ \\
\hline & $\begin{array}{l}\text { Elaeagnus } \\
\text { angustifolia }\end{array}$ & $\begin{array}{l}\text { Yes } \\
(45.13)\end{array}$ & - & Crusts & $\begin{array}{l}\text { Presence of marginally raised stomata and epidermal } \\
\text { cells forming minor grooves. (Fig. 1) }\end{array}$ \\
\hline & Populus alba & $\begin{array}{l}\text { Yes } \\
\text { (sparse) }\end{array}$ & - & Thin film & $\begin{array}{l}\text { Presence of partially sunken stomata and prominent } \\
\text { epidermal cells. (Fig. 1) }\end{array}$ \\
\hline & Ginkgo biloba & No & 56.9 & Tubules & $\begin{array}{l}\text { Presence of sunken stomata and convex epidermal cells. } \\
\text { The adaxial surface shows minor grooves formed } \\
\text { between epidermal cells. (Fig. 1) }\end{array}$ \\
\hline
\end{tabular}




\begin{tabular}{|c|c|c|c|c|c|}
\hline & $\begin{array}{l}\text { Platanus } x \\
\text { acerifolia }\end{array}$ & Yes (2.08) & - & Platelets & $\begin{array}{l}\text { Presence of raised stomata and convex epidermal cells. } \\
\text { Deep grooves are formed in between convex epidermal } \\
\text { cells on the abaxial leaf side but not on the adaxial leaf } \\
\text { side. (Fig. 1) }\end{array}$ \\
\hline & Quercus robur & No & 446.7 & Platelets & $\begin{array}{l}\text { Presence of marginally raised stomata covered with } \\
\text { epicuticular wax crystals. The epidermal cells do not } \\
\text { form deep grooves between cells. (Fig. 1) }\end{array}$ \\
\hline & Quercus petraea & 13.38 & 551.0 & Platelets & $\begin{array}{l}\text { Presence of sunken stomata. The epidermal cells do not } \\
\text { form deep grooves between cells. (Fig. 1) }\end{array}$ \\
\hline & Tilia cordata & No & - & Platelets & $\begin{array}{l}\text { Presence of sunken stomata. The adaxial leaf side shows } \\
\text { convex epidermal cells forming deep grooves in } \\
\text { between cells. (Fig. 1) }\end{array}$ \\
\hline \multirow{5}{*}{$\begin{array}{l}\text { Deciduous } \\
\text { broadleaf } \\
\text { shrubs }\end{array}$} & Buddleja davidii & $\begin{array}{l}\text { Yes } \\
\text { (dense) }\end{array}$ & - & Thin film & $\begin{array}{l}\text { The abaxial surface consists of dense network of } \\
\text { trichomes (for which density could not be determined) a } \\
\text { thin film epicuticular wax layer visible under the } \\
\text { trichomes. The adaxial leaf surface shows marginally } \\
\text { raised stomata and convex epidermal cells forming } \\
\text { grooves in between the cells but no sighting of } \\
\text { trichomes. (Fig. 2) }\end{array}$ \\
\hline & Prunus padus & 0.13 & - & Platelets & $\begin{array}{l}\text { The abaxial surface shows epidermal layer divided into } \\
\text { multiple papillae with dense wax crystals, trichomes and } \\
\text { sunken stomata. The adaxial leaf surface shows convex } \\
\text { epidermal cells covered with wax crystals and form deep } \\
\text { grooves in between cells. (Fig. } 2 \text { ) }\end{array}$ \\
\hline & Salix purpurea & No & 735.9 & Platelets & $\begin{array}{l}\text { The abaxial surface shows epidermal cells with multiple } \\
\text { papillae covered with dense trichomes. The adaxial } \\
\text { surface shows epidermal cells forming deep grooves in } \\
\text { between and are covered with wax crystals. The stomata } \\
\text { appear as sunken on both leaf sides. (Fig. } 2 \text { ) }\end{array}$ \\
\hline & Sambucus nigra & Yes (1.38) & - & Thin film & $\begin{array}{l}\text { Presence of trichomes and marginally raised stomata. } \\
\text { The adaxial leaf side shows convex epidermal cells } \\
\text { forming deep grooves. (Fig. 2) }\end{array}$ \\
\hline & $\begin{array}{l}\text { Viburnum } \\
\text { lantana }\end{array}$ & Yes (8.38) & - & Platelets & $\begin{array}{l}\text { Presence of marginally sunken stomata, prominent } \\
\text { epidermal cells and stellate trichomes. The adaxial leaf } \\
\text { surface shows the epidermal cells forming deep grooves } \\
\text { in between cells. (Fig. 2) }\end{array}$ \\
\hline Climber & Hedera helix & Yes $(0.58)$ & - & Platelets & $\begin{array}{l}\text { Presence of prominent raised stomata and stellate } \\
\text { trichomes. Absence of deep grooves formed between } \\
\text { epidermal cells on both leaf sides. (Fig. 2) }\end{array}$ \\
\hline \multirow{2}{*}{$\begin{array}{l}\text { Evergreen } \\
\text { broadleaf } \\
\text { shrubs }\end{array}$} & $\begin{array}{l}\text { Prunus } \\
\text { laurocerasus }\end{array}$ & No & 179.3 & Thin film & $\begin{array}{l}\text { Presence of raised stomata and trichomes. The } \\
\text { epidermal cells are faintly seen on the abaxial leaf side } \\
\text { but appear smooth on the adaxial leaf side. (Fig. 2) }\end{array}$ \\
\hline & Rhododendron & No & 255.5 & Platelets & $\begin{array}{l}\text { The appearance of epidermal cells forming subtle } \\
\text { grooves between cells and partially raised stomata. No } \\
\text { appearance of trichomes on both leaf sides. (Fig. 2) }\end{array}$ \\
\hline
\end{tabular}

\subsection{Leaf Sampling and Sample Preparation}

Leaf samples were collected twice during the growing season of 2016; first in June ( $9^{\text {th }}$ and $\left.10^{\text {th }}\right)$, second in September $\left(1^{\text {st }}\right.$ and $\left.2^{\text {nd }}\right)$. Only mature, undamaged, and non-infected leaves were collected from the south-east direction of each plant, to eliminate within canopy orientation bias. After harvesting, leaf samples were placed in labeled paper envelopes and transported to the adjacent lab (Laboratory of Environmental and Urban Ecology, University of Antwerp, Belgium) for sample preparation. For particle analyses by SEM only, one plant replicate per species was utilized to determine the particle counts on both the abaxial (AB) and the adaxial (AD) leaf sides. The sample preparation was done using fresh leaf samples. Leaf discs of approximately $12 \mathrm{~mm}$ in diameter were excised and placed on an aluminum stub (Ted Pella Inc.) and affixed in place using conductive double-sided tape (PELCO Tabs $12 \mathrm{~mm}, 16084-1)$. The discs were air dried at room conditions and prior to imaging were coated with a $20 \mathrm{~nm}$ layer of carbon (Leica EM ACE600). Using a Quanta 250 Field Emission 
Gun Environmental Scanning Electron Microscope (FEG-ESEM) and the backscattered electron detector, the leaf deposited particles were analyzed within a specified region. The leaf sample surface was subdivided into 100 fields, each field with an area of $209 \times 144 \mu \mathrm{m}$. with a total surface area of $3.01 \mathrm{~mm}^{2}$ per sample. The distance between the electron emitter and the sample stage was $10 \mathrm{~mm}$. The brightness and contrast settings were set manually based on several particles found on the leaf sample of a specific plant species in order to conceal the leaf micro-morphology in the background while emphasizing only on the particles. This step was performed once before the start of the SEM session for particle count measurements. As such, all leaf samples $(n=4-7)$ on the sample stage during the session had similar brightness and contrast settings. A spot size of 3.5 with a high vacuum setting of $10^{-3} \mathrm{~Pa}$, incident electron energy of $20 \mathrm{kV}$ and magnification of $1000 \mathrm{x}$ was used. Repeated measurements were performed on a subset of plant species to determine the replicability of particle density in two ways: (i) at relatively large time-interval in different SEM sessions (i.e. months to weeks; $n=4$ ) and (ii) at short time-interval within the same SEM session; $n=5$ ). For the first, particles were counted on the same samples from the AB and AD leaf side of four species (G. biloba, B. davidii, E. angustifolia and $V$. lantana), on $16^{\text {th }}$ May and $10^{\text {th }}, 17^{\text {th }}$ and $31^{\text {st }}$ October, 2017 (T1, T2, T3, T4). For the latter, three successive measurements (M1, M2, M3) of particle counts were performed on each leaf side (i.e., $\mathrm{AB}$ and $\mathrm{AD}$ ) of each of these five plant species (Rhododendron, Hedera helix, Quercus robur, Quercus petraea and Sambucus nigra) within the defined leaf sample region and for the same one hundred fields at each iteration. The withinsession successive measurements for a given plant species involving both the $\mathrm{AB}$ and the $\mathrm{AD}$ leaf sides were performed on the same day.

\subsection{Data Analysis}

The particle density based on the equivalent circular diameter (ECD) was estimated on the $\mathrm{AB}$ and the $\mathrm{AD}$ leaf sides of the investigated plant species $(\mathrm{n}=16)$ in the following manner; particles $>10 \mu \mathrm{m}, 10 \geq$ particle diameter $>2.5 \mu \mathrm{m}(\mathrm{coarse})$ and $2.5 \geq$ particle diameter $>0.1 \mu \mathrm{m}$ (fine). The total particle density per plant species was estimated as the sum of particle density on both the $\mathrm{AB}$ and the $\mathrm{AD}$ leaf sides consisting of both coarse and fine particles. A linear mixed effects regression (LMER) [31] was applied on the particle density to examine the effect of particle size fraction (two levels: coarse and fine), time (two levels: June and September), leaf side (two levels: AB and AD) and two-way interaction effects as fixed effects with plant id as a random effect. The response variable particle density was transformed using the natural $\log (\ln )$. A multiple linear regression (MLR) model was applied to determine the effects of leaf traits (trichome and stomatal density, leaf wettability, epicuticular wax structures) on the coarse and fine-particle density on the AB and the AD leaf side in both June and September. Normality of residuals was checked by the Shapiro-Wilk test. The performances of different LMER and MLR model structures were compared using Akaike Information Criterion (AIC). The coefficient of variance (CV), calculated as the ratio of standard deviation to the mean and expressed as percentage was calculated on repeated, (i.e., large time-interval different sessions, and within-session successive) measurements of particle density. The effects of leaf traits on the particle density CV (between 0 and 1) were examined using betareg analyses. All statistical analyses were performed using R 3.2.2 software (R core Team 2015), the Stats package ( $\mathrm{R}$ core Team and contributors worldwide), and the add-on package lmerTest [32]. The XY-plots were generated using the lattice package [33] and stacked bar plots were generated using ggplot2 [34].

\section{Results}

\subsection{Particle Density on Leaves of Investigated Plant Species}

The total particle density ranged from 202 and 10,981 in June and 30 and 1,984 particles $\mathrm{mm}^{-2}$ in September. In June, on the AB leaf side (Fig. 3a), the coarse-particle density ranged from 3 to 269 particles $\mathrm{mm}^{-2}$ and fine-particle density ranged from 42 to 1,963 particles $\mathrm{mm}^{-2}$ with the lowest density for both particle size fractions were observed on leaves of $T$. cordata and highest on leaves of $V$. lantana. In June, on the AD leaf side (Fig. 3b), the coarse-particle density ranged from 7 to 709 particles $\mathrm{mm}^{-2}$ with the lowest and highest particle density observed on leaves of $Q$. robur and $B$. davidii respectively. The fine-particle density on the AD leaf side ranged from 108 to 9,116 particles $\mathrm{mm}^{-2}$ with the lowest and highest density observed on leaves of S. purpurea and B.davidii respectively. In September, on the AB leaf side (Fig. 3c), the coarse-particle density ranged from 0 to 170 particles $\mathrm{mm}^{-2}$, and the fine-particle density ranged from 22 to 1,620 particles $\mathrm{mm}^{-2}$. The lowest and the highest coarse and fine-particle density was observed on leaves of G. biloba and P. alba respectively. In September, on the $\mathrm{AD}$ leaf side (Fig. 3d), the coarse-particle density ranged from 0 to 72 particles $\mathrm{mm}^{-2}$, and the fine-particle density ranged between 2 to $739 \mathrm{~mm}^{-2}$. No coarse-particles were detected by SEM on leaves of $Q$. robur and G. biloba while the highest 
coarse-partilce density was observed on leaves of $V$. lantana. In September, on the AD leaf side, the lowest and highest fineparticle density was observed on leaves of $Q$. robur and $Q$. petraea, respectively.

\subsection{Particle Density: Effect of Time, Leaf Sides and Particle Size Fraction}

The results of the linear mixed effects regression (LMER) model (Table 4) indicated a significant negative effect of time on particle density $(p=0.004)$. The particle density (mean \pm SE) decreased from June $(1807 \pm 765)$ to September $(662 \pm$ 115). A positive significant effect of leaf side on particle density was indicated ( $p<0.001)$. The particle density on the AD leaf side was 2.6 times higher than the particle density on the AB leaf side. The effect of particle size fraction was indicated to be significant $(\mathrm{p}<0.001)$. The coarse-particle density was significantly lower than fine-particle density. The interaction effects between time, leaf sides and particle size fraction on total particle density were indicated to be insignificant.

\subsection{Particle Density: Effect of Leaf Traits}

In June, the effect of trichome density was significant and positive on both leaf sides (Fig. 4a, c) and for coarse and fineparticles (Table 4). The coarse and fine-particle density increased with increasing trichome density. In September, no significant effect of any leaf trait was indicated on either leaf sides (AB and AD) and for both coarse and fine-particles (Table 4). The XY scatter plot for the AD leaf side (Fig. 4d) suggests a positive relationship between trichome and particle density but was not indicated by the LMER.

\subsection{Repeated Measurements}

The repeated measurements were initially performed on seven samples at large time-intervals in different SEM sessions (Table 2). The coefficient of variance (CV) of these repeated measurements were high and differed between plant species. Additionally, the CV differed between particle size fractions and leaf sides. The large time-interval measurements failed to explain the reasons for discrepancies in particle density due to the large CV values, hence successive repeated measurements were performed. The within-session successive measurements results (Table 3) showed notably smaller CV values. The CV on the $\mathrm{AB}$ leaf side ranged from 0 to $50 \%$ and 3 to $37 \%$ for coarse and fine-particles respectively whereas the $\mathrm{CV}$ on the $\mathrm{AD}$ leaf side ranged from 1 to $25 \%$ and 3 to $20 \%$ for coarse and fine-particles respectively. Additionally it was observed that the CV increased with an increasing complexity in leaf micro-morphology $(Q$. robur $=S$. nigra $>Q$. petraea $=H$. helix $>$ Rhododendron). However, the effect of leaf traits on CV (Table 5) on the AB and the AD leaf side were indicated to be not significant for both the coarse and the fine-particles.

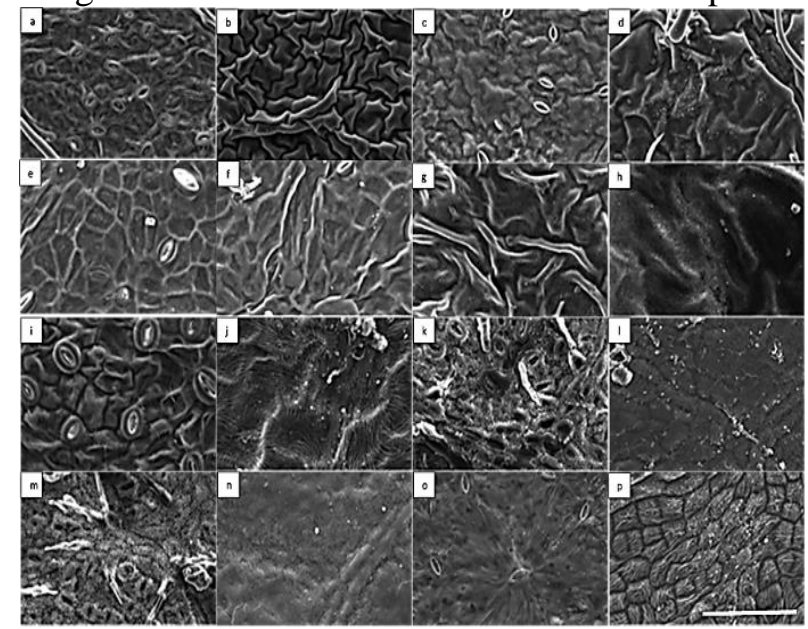

Fig. 1 Scanning electron micrographs showing leaf micro-morphology of deciduous broadleaf trees on the abaxial (first and third column) and the adaxial (second and fourth column) leaf sides respectively of $(\mathrm{a}-\mathrm{b})$ Catalpa bignonioides, (c - d) Elaeagnus angustifolia, (e - f) Populus alba, $(\mathrm{g}-\mathrm{h})$ Ginkgo biloba, $(\mathrm{i}-\mathrm{j})$ Platanus $x$ acerifolia, $(\mathrm{k}-\mathrm{l})$ Quercus robur, $(\mathrm{m}-\mathrm{n})$ Quercus petraea, $(\mathrm{o}-\mathrm{p})$ Tilia cordata. Scale bar $(\mathrm{a}-\mathrm{p})=100 \mu \mathrm{m}$.

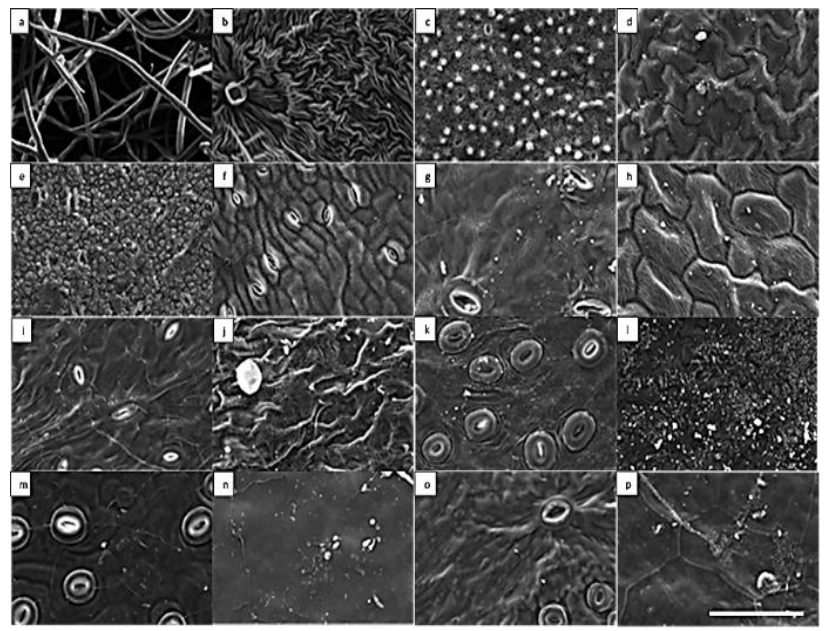

Fig. 2 Scanning electron micrographs showing leaf micromorphology of deciduous and evergreen broadleaf shrub and climber species on the abaxial and the adaxial leaf sides respectively of $(\mathrm{a}-\mathrm{b})$ Buddleja davidii, $(\mathrm{c}-\mathrm{d})$

Prunus padus, (e - f) Salix purpurea, $(\mathrm{g}-\mathrm{h})$ Sambucus nigra, $(\mathrm{i}-\mathrm{j})$ Viburnum lantana, $(\mathrm{k}-\mathrm{l})$ Hedera helix, $(\mathrm{m}-$ n) Prunus laurocerasus, (o - p) Rhododendron. Scale bar $(\mathrm{a}-\mathrm{p})=100 \mu \mathrm{m}$ 


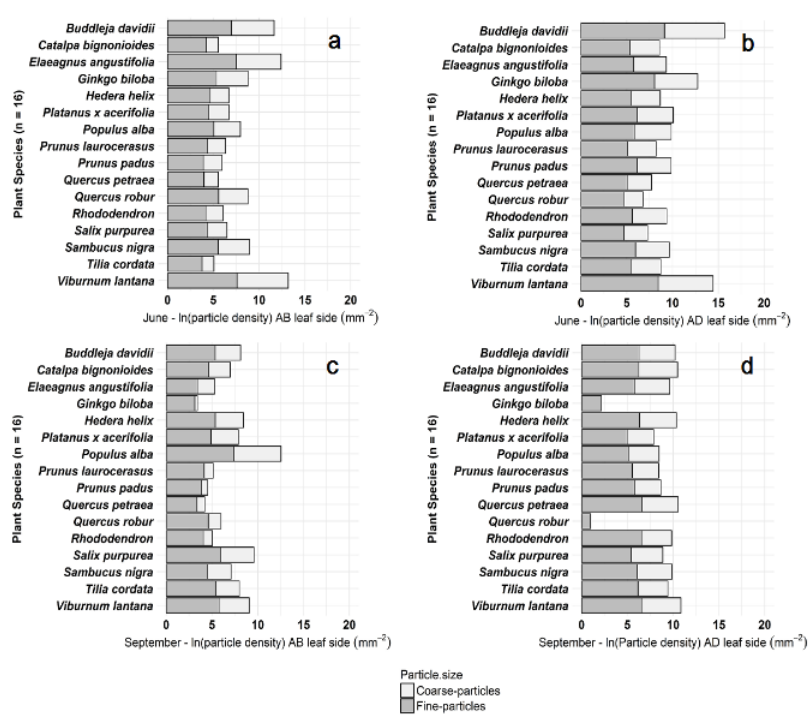

Fig. 3 Natural log transformed particle density (number of particles divided by the area $(3.01 \mathrm{~mm}-2)$ examined under SEM) on the abaxial [AB: $(\mathrm{a}, \mathrm{c})]$ and the adaxial [AD: (b, d)] leaf sides of the investigated plant species (n =16) analyzed in June (a, b) and September (c, d) 2016.

Light gray bars indicate coarse particles $(2.5-10 \mu \mathrm{m})$ and dark gray bars indicate fine particles $(0.2-2.5 \mu \mathrm{m})$.

The total length of the bars in each graph indicate the total particle density, (i.e., $\sum$ coarse and fine-particles).

Table 2 Average particle density and its standard deviation (SD) and coefficient of variation (CV: \%) from (multiple sessions) long time-interval repeated measurements for coarse and fine-particle density on the abaxial (AB) and the adaxial (AD) leaf side of the selected plant species $(n=4)$ with contrasting leaf micro-morphology. The long timeinterval measurements were performed on $16^{\text {th }}$ May, $10^{\text {th }}$ October, $17^{\text {th }}$ October, and $31^{\text {st }}$ October 2017 (T1, T2, T3, $\mathrm{T} 4)$ respectively. The average, standard deviation (SD) and coefficient variance (CV) expressed as percentage are based on the four repeated measurements of particle density. The missing data are indicated by a hyphen "-".

\begin{tabular}{lllll}
\hline Species & \multicolumn{2}{l}{ Abaxial (AB) } & \multicolumn{2}{l}{ Adaxial (AD) } \\
\hline & Coarse & Fine & Coarse & Fine \\
\hline Ginkgo biloba & & & & \\
T1 & & & & \\
T2 & 0 & 22 & 0 & 8 \\
T3 & 31 & 264 & 8 & 72 \\
T4 & 34 & 255 & 3 & 51 \\
& 1 & 39 & 0 & 5
\end{tabular}
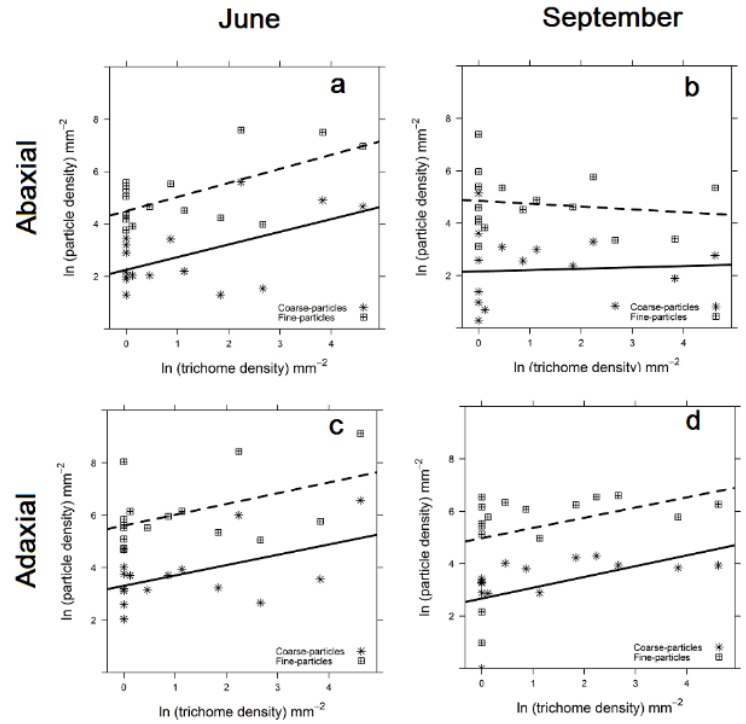

Fig. 4 The XY-plot illustrating the relationship between natural log-transformed trichome density and natural logtransformed particle density normalized by leaf area examined under SEM (3.01 mm2) consisting of [coarse $(2.5-10 \mu \mathrm{m})$ and fine $(0.2-2.5 \mu \mathrm{m})]$ particles analyzed in

(a) June on the abaxial (c) June on the adaxial, (b) September on the abaxial, (d) September on the adaxial leaf sides. The lines represent fitted regression lines; solid for coarse-particles and dashed for fine-particles.

Table 3 Average particle density and its standard deviation (SD) and coefficient of variation (CV: \%) from (within-session) repeated measurements for coarse and fine-particle density on the abaxial $(\mathrm{AB})$ and the adaxial (AD) leaf side of the selected plant species $(n=5)$ with contrasting leaf micro-morphology. Repeated measurements were performed within a specified region on the leaf sample and one-hundred random fields were examined using SEM. Three consecutive measurements of particle counts are denoted as (M1, M2, and M3). The average, standard deviation (SD) and coefficient variance

(CV) expressed as percentage are based on the three repeated measurements of particle counts.

\begin{tabular}{lcccc}
\hline Species & \multicolumn{2}{c}{ Abaxial (AB) } & \multicolumn{2}{c}{ Adaxial (AD) } \\
\hline \multicolumn{2}{r}{ Coarse } & Fine & Coarse & Fine \\
\hline Rhododendron & & & & \\
M1 & 245 & 5794 & 138 & 915 \\
M2 & 230 & 5648 & 138 & 933 \\
M3 & 207 & 4966 & 135 & 873 \\
Average & 227 & 1764 & 137 & 907 \\
SD & 19 & 143 & 2 & 31 \\
CV & $\mathbf{8}$ & $\mathbf{8}$ & $\mathbf{1}$ & $\mathbf{3}$ \\
Hedera helix & & & & \\
M1 & 64 & 804 & 75 & 1165 \\
M2 & 60 & 655 & 73 & 1091
\end{tabular}




\begin{tabular}{|c|c|c|c|c|c|c|c|c|c|}
\hline \multirow[t]{2}{*}{ Average } & & & & & M3 & 56 & 575 & 71 & 1067 \\
\hline & 17 & 145 & 3 & 34 & Average & 60 & 678 & 73 & 1107 \\
\hline \multirow[t]{2}{*}{ SD } & & & & & SD & 4 & 117 & 2 & 51 \\
\hline & 19 & 132 & 4 & 33 & $\mathrm{CV}$ & 7 & 17 & 3 & 5 \\
\hline $\mathrm{CV}$ & 112 & 91 & 137 & 97 & Quercus & & & & \\
\hline \multirow{2}{*}{\multicolumn{2}{|c|}{ Buddleja davidii }} & & & & M1 & 7 & 160 & 3 & 72 \\
\hline & & & & & M2 & 21 & 342 & 3 & 77 \\
\hline \multirow[t]{2}{*}{$\mathrm{T} 1$} & & & & & M3 & 23 & 356 & 4 & 85 \\
\hline & 50 & 467 & 8 & 90 & Average & 17 & 286 & 3 & 78 \\
\hline \multirow[t]{2}{*}{$\mathrm{T} 2$} & & & & & SD & 8 & 110 & 1 & 7 \\
\hline & 30 & 439 & 9 & 228 & $\mathrm{CV}$ & $\mathbf{5 0}$ & 38 & 17 & 9 \\
\hline T3 & 21 & 349 & 7 & 113 & Quercus & & & & \\
\hline \multirow{3}{*}{$\begin{array}{l}\text { T4 } \\
\text { Average }\end{array}$} & 0 & 39 & 0 & 4 & M1 & 1 & 44 & 5 & 99 \\
\hline & & & & & M2 & 1 & 47 & 6 & 118 \\
\hline & 25 & 324 & 6 & 109 & M3 & 1 & 50 & 6 & 125 \\
\hline \multirow[t]{2}{*}{ SD } & & & & & Average & 1 & 47 & 6 & 114 \\
\hline & 21 & 196 & 4 & 92 & SD & 0 & 3 & 1 & 13 \\
\hline \multirow[t]{2}{*}{$\mathrm{CV}$} & & & & & $\mathrm{CV}$ & $\mathbf{0}$ & 7 & 10 & 12 \\
\hline & 82 & 61 & 68 & 85 & Sambucu & & & & \\
\hline \multicolumn{3}{|c|}{ Elaeagnus angustifolia } & & & M1 & 306 & 8508 & 327 & 27420 \\
\hline \multirow{2}{*}{$\mathrm{T} 1$} & & & & & M2 & 196 & 5352 & 212 & 18819 \\
\hline & & & - & - & M3 & 160 & 4257 & 225 & 20605 \\
\hline \multirow{2}{*}{$\mathrm{T} 2$} & 19 & 131 & - & - & Average & 220 & 6039 & 254 & 22281 \\
\hline & 25 & 134 & - & - & SD & 76 & 2207 & 63 & 4539 \\
\hline \multirow[t]{2}{*}{$\mathrm{T} 3$} & & & - & - & $\mathrm{CV}$ & 35 & 37 & 25 & 20 \\
\hline & 12 & 147 & & & & & & & \\
\hline \multirow{3}{*}{$\begin{array}{l}\text { T4 } \\
\text { Average }\end{array}$} & 0 & 25 & - & - & & & & & \\
\hline & & & - & - & & & & & \\
\hline & 14 & 109 & & & & & & & \\
\hline \multirow[t]{2}{*}{ SD } & & & - & - & & & & & \\
\hline & 11 & 57 & & & & & & & \\
\hline \multirow[t]{2}{*}{$\mathrm{CV}$} & & & - & - & & & & & \\
\hline & 77 & 52 & & & & & & & \\
\hline \multicolumn{10}{|c|}{ Viburnum lantana } \\
\hline $\mathrm{T} 1$ & 110 & 3098 & 31 & 205 & & & & & \\
\hline $\mathrm{T} 2$ & 166 & 6397 & 66 & 864 & & & & & \\
\hline $\mathrm{T} 3$ & 96 & 3614 & 25 & 279 & & & & & \\
\hline $\mathrm{T} 4$ & 16 & 768 & 1 & 11 & & & & & \\
\hline \multicolumn{10}{|l|}{ Average } \\
\hline & 97 & 3469 & 31 & 340 & & & & & \\
\hline SD & & & & & & & & & \\
\hline \multirow[t]{2}{*}{$\mathrm{CV}$} & 62 & 2311 & 27 & $\begin{array}{l}367 \\
\mathbf{1 0 8}\end{array}$ & & & & & \\
\hline & 64 & 67 & 87 & & & & & & \\
\hline
\end{tabular}


Table 4 The multiple linear regression ANOVA of predictor variables (i.e., leaf traits); TR (Trichome density), SD (Stomatal density), EWS (epicuticular wax structures), DCA (drop contact angles) indicating an effect on natural log-transformed $\ln$ (particle density) analyzed on the abaxial $(\mathrm{AB})$ and the adaxial (AD) leaf sides for coarse (10 $-2.5 \mu \mathrm{m})$ and fine particles $(2.5-0.2 \mu \mathrm{m})$ in June and September. Significant effects $(p \leq 0.05)$ are shown in bold.

\begin{tabular}{|c|c|c|c|c|c|}
\hline Response & $\begin{array}{c}\text { Fix } \\
\text { ed } \\
\text { Eff } \\
\text { ect } \\
\text { s }\end{array}$ & $\begin{array}{c}\mathrm{F} \\
\text { valu } \\
\mathrm{e}\end{array}$ & $\begin{array}{c}\mathrm{p} \\
\mathrm{val} \\
\mathrm{ue}\end{array}$ & $\begin{array}{c}\text { F } \\
\text { va } \\
\text { lu } \\
\text { e }\end{array}$ & $\begin{array}{c}\mathrm{p} \\
\text { val } \\
\text { ue }\end{array}$ \\
\hline & & \multicolumn{2}{|c|}{ Abaxial } & \multicolumn{2}{|c|}{ Adaxial } \\
\hline Coarse-June & TR & 5.74 & 0.031 & 7.54 & 0.016 \\
\hline Fine-June & TR & 7.80 & 0.014 & 6.62 & 0.022 \\
\hline Coarse-Sept & TR & 0.06 & 0.801 & 1.43 & 0.258 \\
\hline \multirow{7}{*}{ Fine-Sept } & SD & 0.26 & 0.617 & - & - \\
\hline & EWS & 1.73 & 0.228 & 2.51 & 0.117 \\
\hline & DCA & 0.22 & 0.650 & 0.22 & 0.649 \\
\hline & $\mathrm{TR}$ & 0.01 & 0.939 & 0.72 & 0.415 \\
\hline & SD & 0.11 & 0.746 & - & - \\
\hline & EWS & 1.66 & 0.243 & 1.46 & 0.282 \\
\hline & DCA & 0.39 & 0.544 & 0.87 & 0.371 \\
\hline
\end{tabular}

Table 5 Summary of betareg analyses to determine the effect of leaf traits [stomatal density (SD), drop contact angles (DCA) and trichome density (TR)] on the coefficient of variance (CV) calculated from withinsession successive repeated measurements $(n=3)$ for the coarse and the fine-particle density analyzed on the abaxial $(\mathrm{AB})$ and the adaxial (AD) leaf side of 5 perennial deciduous and evergreen plant species.

\begin{tabular}{cccc}
\hline Response & Effect & $\begin{array}{c}\text { Estimate } \\
\text { effect size }\end{array}$ & p value \\
\hline $\mathrm{AB}$ (coarse) & $\mathrm{SD}$ & -0.002 & 0.317 \\
& $\mathrm{DCA}$ & 0.022 & 0.117 \\
& $\mathrm{TR}$ & -0.114 & 0.081 \\
$\mathrm{AB}$ (fine) & $\mathrm{SD}$ & -0.002 & 0.271 \\
& $\mathrm{DCA}$ & 0.022 & 0.114 \\
& $\mathrm{TR}$ & -0.101 & 0.112 \\
$\mathrm{AD}$ (coarse) & $\mathrm{DCA}$ & 0.014 & 0.436 \\
& $\mathrm{TR}$ & 0.024 & 0.717 \\
$\mathrm{AD}$ (fine) & $\mathrm{DCA}$ & -0.005 & 0.721 \\
& $\mathrm{TR}$ & 0.044 & 0.343 \\
& & & \\
\hline
\end{tabular}

\section{Discussion}

The investigated plant species showed an effectiveness in distinctively collecting particles on their leaf surfaces. The particle densities observed on leaf surfaces of the investigated plant species in this study were notably low when compared with the reported findings of Weerakkody et al. [28] and Blanusa et al. [35]. A direct comparison of results from the present study to those of previous studies may be difficult due to the differences in sampling methodologies, sampling locations and plant species. A significant decrease in particle density was observed from June to September, which is a rather unexpected outcome when comparing with findings of the past studies. As plant surfaces remain in constant contact with their environments they experience repeated episodes of PM exposure, wind and rain resulting in continuous accumulation and removal of particles. The decrease in particle density with time was not a plant species-specific observation but an observation for most investigated plant species. A plausible reason could be that the same samples were also used in a separate study of Muhammad et al. [25] for imaging of epicuticular wax structures (EWS) but due to reduction in clustering of wax crystals in September, the examination time was longer than usual. As a result a charging effect was frequently experienced, where a build-up of static electric charge influences the electron signals and deteriorates the image information. Concerning the differences in particle density on both leaf sides (AB, AD), the particle density was indicated to be more than two times as high on the $\mathrm{AD}$ leaf side compared to the $\mathrm{AB}$ leaf side as was observed by Ottele et al.[27]. A higher particle density on the AD leaf side was observed in both June and September and for both size fractions (coarse, fine-particles). It is possible that the AD leaf side due to its orientation in space accumulates more particles through increased sedimentation of particles on the $\mathrm{AD}$ side, although a higher resuspension at the $\mathrm{AD}$ side would also be expected as it is more exposed to rain than the $\mathrm{AB}$ side. The effect of particle size fraction in this study was indicated to be significant and independent of leaf side and time. The fine-particle density was significantly higher than coarse-particle density. The fine-particle fraction contributed on average by $91 \%$ to the total particle density (fine + coarse). The higher fine-particle density was consistent with the reported findings of, e.g., Ottelé et al. [27], Weerakkody et al. [28], and Freer-Smith et al. [36]. The higher incidence of fine-particles than coarse-particles in terms of counts or density could be as large particles are more easily resuspended in the air compared to small particles [37], hence resulting in low density of coarse particles as observed in this study. Nicholson [38] demonstrated that the rate of particle resuspension increases with an increase in particle diameter because the drag forces increase quickly compared to adhesive forces [39]. Besides, large particles are protruded further into the turbulent air stream making them prone to resuspension [40]. A significant positive effect of trichome density on the $\mathrm{AB}$ and the AD particle 
density was indicated for both coarse and fine-particles in June. The fine and coarse-particle density increased with an increase in trichome density (Fig. 4a) which corresponds with the findings of studies based on particle mass and on leaf SIRM [2-5, 7, 9, 36, 41-42]. Chen et al. [43] highlighted that the presence of trichomes itself does not ensure an enhanced particle deposition but rather the trichome density is of importance. The presence of trichomes increases the surface area on the leaves where particles can be deposited [44]. To the best of our knowledge, this study is the first to show that the trichome density influences the number of particles accumulated in both coarse and fine size fraction, ruling out the possibility of trichome density shifting the distribution of accumulated particles towards coarser particles, thereby increasing the accumulation effectiveness of the coarse fraction only and hereby increasing the mass but not the number of particles accumulated. The lack of trichome density effect for both coarse and fine-particles on both AB and AD leaf side in September was rather an unexpected and contrary to the findings in June.

To identify the basis of disparity in particle density between measurements, the repeated measurements were initially performed at large time-intervals. However, the CV estimated on leaves with trichomes was large and ranged from 52 to 137 $\%$ on both leaf sides and consisting of both coarse and fine-particles. We were unable to identify the exact cause of discrepancies in particle density between measurements with at large time-interval repeated measurements. Therefore, a new subset of plant species was selected possessing simple to complex leaf micro-morphology for within-session successive repeated measurements. The within-session successive repeated measurements overall showed small CV values ranging from $1-50 \%$. Furthermore, the within-session successive repeated measurements illustrated that as the complexity in leaf micromorphology increases so did the $\mathrm{CV}$ of mean particle density $(Q$. robur $=S$. nigra $>Q$. petraea $=H$. helix $>$ Rhododendron $)$. The highest CV was estimated on leaves of $Q$. robur on the AB leaf side and on $S$. nigra on the AD leaf sides. We suppose that leaves of $Q$. robur and $S$. nigra with micro-protuberances in the form of raised stomata, epicuticular wax crystals, dense venation, trichomes and convex epidermal cells (Table 2) possibly resulted in an impediment of accurate particle recognition. Although no significant effect of leaf traits on CV were indicated (Table 5), the SEM images (Fig. 5 a $-\mathrm{f}$ ) sufficiently illustrate that leaf micromorphology contributed to the inconsistency in particle density measurements. Postek and Vladár [45] demonstrated that as the beam in a secondary electron image (SEI) approaches an edge of a surface (i.e., trichomes, raised stomata) it generates more secondary electron signal resulting in enhancement of the topographical features (Fig. 5 a - f). To verify the edge enhancement effects, we compared the SEI and BSE images of $S$. nigra simultaneously. It was observed that edge enhancement effect was not limited to only the micro-morphological features of the leaf surface (Fig. 5) but also occurred in situations when biological material such as insects were found on the leaf sample (Fig. 5 a, b). Hence, we conclude that measurements of particle density using SEM are complicated by the presence of trichomes, raised stomata and/or convex epidermal cells contributing to the edge enhancement effects.

A detailed examination of BSE images of $S$. nigra, it was revealed that the leaf sample of $S$. nigra encountered a mechanical drift during successive measurements. The drift in Figure 5 may not be obvious initially but a more thorough observation reveals that the particle highlighted in green in (Fig. 5g) appears in the top right corner whereas in (Fig. 5h) it appears even further in the top right corner. Moreover, two more particles appear in (Fig. 5h) on the lower left side which were absent in (Fig. 5g). A mechanical drift typically occurs because the column of SEM is directly coupled to the sample stage and any external vibrations transmitted through the frame and isolation system to the column can be transferred to the sample resulting in undesirable artefacts [46]. The reduction in particle density (coarse and fine) at each subsequent iteration (Table 3) on both the $\mathrm{AB}$ and the $\mathrm{AD}$ leaf side were likely due to the charging effect on the leaf sample. The build-up of voltage on the leaf sample may cause significant variation in the number of secondary electrons detected, resulting in charging artefacts [47-49]. Furthermore, particles which are marginally adhered to the leaf surface tend to blast-off and disappear permanently upon negative charging [50]. It is possible to decrease this charging effect by coating the leaf samples with a thin layer of conducting material, although it does not seem to be possible to achieve a completely conductive coating [51]. Based on (i) on the order of magnitude of the particle density data for June and (ii) the significant positive effect of trichome density on particle density for both coarse and fine-particles we believe that SEM will continue to be a useful methodology for analyzing particle density in addition to the particle shape, size and elemental composition. However, like any other scientific instrument, SEM has its limitations for particle counting, as observed in our study due to edge enhancement, charging effects and mechanical drift. Furthermore, Burkhardt [52] pointed out that particles those arrive on the leaf surface in liquid phase, remain amorphous rather than becoming crystalline, this makes them difficult to see by SEM resulting in an underestimation of particles. These shortcomings should not be overlooked. We remain convinced that leaf samples from September endured excessive charging effect leading to contradictory and inconclusive results. In order to 
obtain reliable quantitative data for particle density using SEM, the within-session successive repeated measurements $(\sim \mathrm{n} \geq$ 5) need to be a preferred practice.
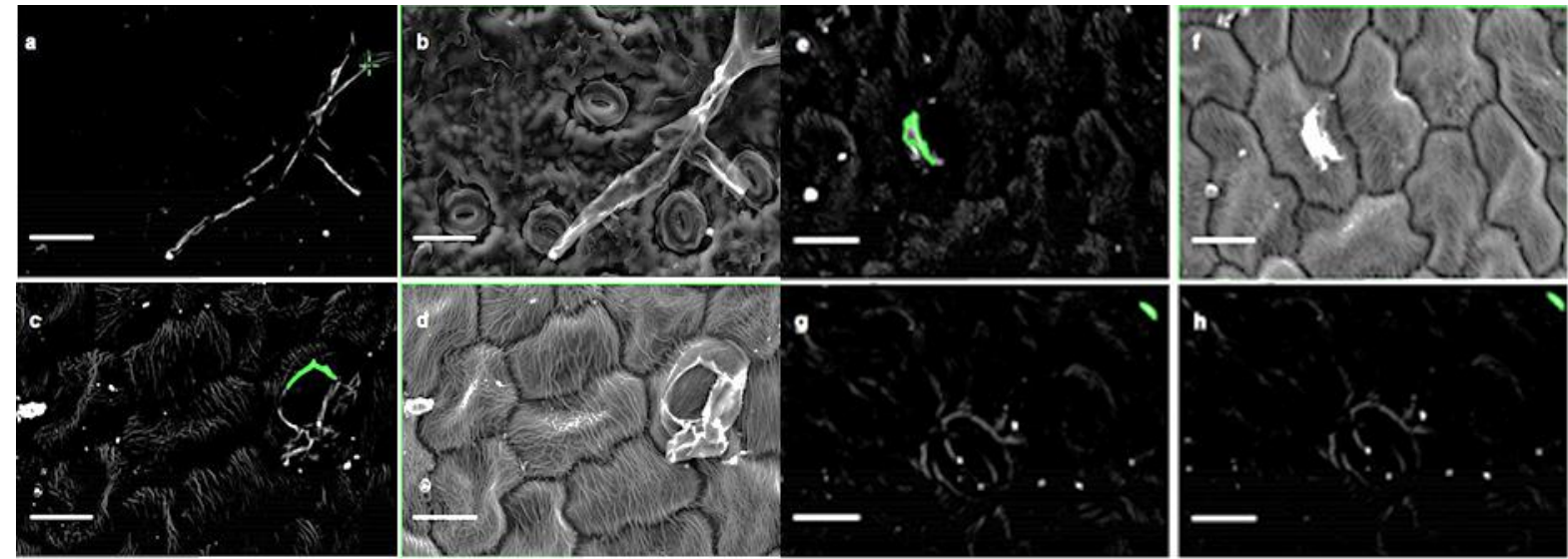

Fig. 5 A comparison of backscattered electron image (a, c, e, g, h) with secondary electron image (b, d, f) illustrating the edge enhancement effect $(\mathrm{a}-\mathrm{f}$ ) on leaves of H. helix ( $\mathrm{a} \& \mathrm{~b}$ ) and S. nigra (c to f). Drifting of leaf sample illustrated on leaves of S. nigra (g and h) although subtle, the particle highlighted in green in Fig. 5g appears in the top right corner whereas in Fig. 5h it appears further in the top right corner. Moreover, two more particles appear in Fig. $5 \mathrm{~h}$ on the lower left side which were absent in Fig. $5 \mathrm{~g}$.

\section{Conclusion}

Scale bar $(\mathrm{a}-\mathrm{h}=100 \mu \mathrm{m})$.

The investigated plant species showed a variation in density of accumulated particles. In addition, more particles accumulated on the AD leaf side than the AB leaf side and the density of fine-particles was higher than the density of coarseparticles. The particle density was influenced by leaf traits, as the particle density in June increased with an increase in trichome density. The particle density in September was lower compared to June even after a longer exposure period and could not be related with the considered leaf traits. These findings compelled us to question the reliability of the methodology for particle counting. Our study provides insights on how the complexity of leaf micro-morphology may hinder in particle recognition and accuracy of particle density estimated on leaf surfaces using SEM. The successive repeated measurements enabled us to identify three commonly occurring perils of SEM when estimating particle density on leaf surfaces with complex micro-morphology. First, the edge enhancement effect was frequently observed on leaves with pronounced micromorphology because the electron beam generates more secondary electron signal as it scans through those topographical features resulting in the edge enhancement effect and leading to erroneous particle recognition. Second, it was identified that a mechanical drift was another likely cause that contributed in disparity of particle density. Third, the reduction in particle density between successive measurements were imputed on charging effects of the leaf sample due its non-conductive nature. Considering those particles which are loosely adhered to the leaf surface, a negative charging may blast-off those particles permanently causing a reduction in particle density. Based on the findings of June, we believe that SEM will continue to be a useful methodology for analyzing particle density on leaf surfaces. As for the contradictory and inconclusive results of September, we recommend that within-session successive repeated measurements $(\sim n \geq 5)$ need to be performed to remove measurement uncertainties and obtain reliable quantitative data using SEM.

\section{Acknowledgements}

The research was funded by the Ontario Student Assistance Program (OSAP \# 15103399) and the University of Antwerp. The authors would like to thank Gert Nuyts for his technical support and SEM imaging and the ENdEMIC group in the management and up keep of the common-garden.

\section{References}

[1] Farmer A. 2002. Effects of particulates. Bell J.N.B, Treshow M, Editors Air pollution and Plant life. Hoboken (NJ): John Wiley \&Sons, Inc $187-99$.

[2] Mitchell, R., Maher, B.A., Kinnersley, R., 2010. Rates of particulate pollution deposition onto leaf surfaces: Temporal and interspecies magnetic analyses. Environmental Pollution 158: 1472-1478. 
[3] Dzierzanowski, K., Popek, R., Gawronska,H., Saebo, A., Gawronski, S.W., 2011. Accumulation of particulate matter by several plant species in regard to PM fractions and deposition on leaf surface and in waxes. International Journal of Phytoremediation 13: 1037 - 46.

[4] Sæbø, A. Popek,R., Nawrot,B., Hanslin,H.M., Gawrońska, H.,Gawroński,S.W., 2012. Plant species differences in particulate matter accumulation on leaf surfaces. Science of Total Environment 427-428: 347 - 354.

[5] Popek, R., Gawrońska, H., Wrochna, M., Gawroński, S.W., Sæbø, A., 2013. Particulate matter on foliage of 13 woody species: Deposition on surfaces and phytostabilisation in waxes - a 3-year study. International Journal of Phytoremediation 15: 245 256.

[6] Przybysz, A., Sæbø, A., Hanslin, H.M., Gawroński, S.W., 2014. Accumulation of particulate matter and trace elements on vegetation as affected by pollution level, rainfall and the passage of time. Science of Total Environment 481: 360 - 69.

[7] Muhammad, S., Wuyts, K., Samson, R., 2019. Atmospheric net particle accumulation on 96 plant species with contrasting morphological and anatomical leaf characteristics in a common garden experiment. Atmospheric Environment 202: 328 344.

[8] Jouraeva, V.A., Johnson, D.L., Hassett, J.P., Nowak, D.J., 2002. Differences in accumulation of PAHs and metals on leaves of Tilia x euchlora and Pyrus calleryan. Environmental Pollution 120: 331 - 338.

[9] Freer-Smith, P.H., El-Khatib, A.A., Taylor, G., 2004.Capture of Particulate Pollution by Trees: A Comparison of Species Typical of Semi-Arid Areas (Ficus Nitida and Eucalyptus Globulus) with European and North American Species. Water Air and Soil pollution. 155: $173-187$.

[10] Terzaghi, E., Wild, W., Zacchello, G., Cerabolini, B.E.L., Jones, K.C., Di Guardo, A., 2013. Forest filter effect: Role of leaves in capturing / releasing air particulate matter and its associated PAHs. Atmospheric Environment 74: 378 - 384.

[11] Li, X., Wang, L., Wang, Y., Wen, T., Yang, Y., Zhao, Y., Wang, Y., 2012. Chemical composition and size distribution of airborne particulate matters in Beijing during the 2008 Olympics. Atmospheric Environment 50: 278 - 286.

[12] Matzka, J., Maher, B. A., 1999. Magnetic biomonitoring of roadside tree leaves: Identification of spatial and temporal variations in vehicle derived particles. Atmospheric Environment. 33: 4565 - 4569.

[13] Urbat, M., Lehndroff, E., Schwark, 1., 2004. Biomonitoring of air quality in the Cologne conurbation using pine needles as a passive sampler-part |: magnetic properties. Atmospheric Environment 38: 3781-3792.

[14] Tomaš̉ević, M., Vukmirović, Z., Rajšić, S., Tasić, M., Stevanović. B., 2005. Characterization of trace metals particles deposited on some deciduous tree leaves in an urban area. Chemosphere 61: 753 -760.

[15] Goldstein, J., Newbury, D., Joy, D., Lyman, C., Echlin, P., Lifshin, E., Sawyer, L., Michael, J., Scanning electron microscopy and X-Ray microanalysis 3rd Ed. USA: Springer 2003.

[16] Stokes, D.J., Principles and practice of variable pressure/environmental scanning electron microscopy (VP-SEM). UK: John Wiley and Sons Ltd; 2008.

[17] Talbot, M.J., White, R.G., 2013. Cell surface and cell outline imaging in plant tissues using backscattered electron detector in a variable pressure scanning electron microscope. Plant Methods 9: 40.

[18] Winter, N., Scanning Electron Microscopy of Cement and Concrete. 2012. WHD Microanalysis Consultants Ltd. pages 1 20.

[19] Neinhuis, C., Barthlott, W., 1997. Characterization and distribution of water-repellent, self-cleaning plant surfaces. Annals of Botany 79: 667 - 677.

[20] Barthlott, W., Neinhuis, C., Cutler, D., Ditsch, F., Meusel, I., Theisen, I., Wilhelmi, H., 1998. Classification and terminology of plant epicuticular waxes. Botanical Journal of the Linnean Society 126: $237-260$.

[21] Wagner, P., Fürstner, R., Barthlott, W., Neinhuis, C., 2003. Quantitative assessment to the structural basis of water repellency in natural and technical surfaces. Journal of Experimental Botany 54: 1295 - 1303.

[22] Shepherd, T., Griffiths, D.W., 2006. The effects of stress on plant cuticular waxes. New Phytologist 171: 469 - 499.

[23] Bhushan, B., Jung, Y.C., 2008. Wetting, adhesion and friction of superhydrophobic and hydrophylic leaves and fabricated micro/nanopatterned surfaces. Journal of Physics: Condensed Matter 20: 225010.

[24] Koch, k., Ensikat, H.J., 2008. The hydrophobic coatings of plant surfaces: Epicuticular wax crystals and their morphologies, crystallinity and molecular sel-assembly. Micron 39: $759-772$.

[25] Muhammad. S., Wuyts, K., Nuyts, G., De Wael, K., Samson, R., 2020. Characterization of epicuticular wax structures on leaves of urban plant species and its association with leaf wettability. Urban Forestry and Urban Greening 47: 126557.

[26] Neinhuis, C., Barthlott, W., 1998. Seasonal changes of leaf surface contamination in beech, oak, and ginkgo in relation to leaf micromorphology and wettability. New Phytologist 138:91-98.

[27] Ottelé, M., van Bohemen, H.D., Fraaij, A.L.A., 2010. Quantifying the deposition of particulate matter on climber vegetation on living walls. Ecological Engineering 36: 154 - 162. 
[28] Weerakkody, U., Dover, J.W., Mitchell, P., Reiling, K., 2017. Particulate matter pollution cpture by leaves of seventeen living wall species with special reference to rail-traffic at a metropolitan station. Urban Forestry and Urban Greening 27: 173 - 186.

[29] Song, Y., Maher, B.A., Li, F., Wang, X., Sun, X., Zhang, H. 2015. Particulate matter deposited on leaf of five evergreen species in Beijing, China: Source identification and size distribution. Atmospheric Environment 105: 53-60.

[30] Weerakkody, U., Dover, J. W., Mitchell, P., Reiling, K., 2018. Evaluating the impact of individual leaf traits on atmospheric particulate matter accumulation using natural and synthetic leaves. Urban Forestry and Urban Geening 30: 98 - 107.

[31] Bates, D., Mächler, M., Bolker, B., \& Walker, S. (2015). Fitting Linear Mixed-Effects Models Using lme4. Journal of Statistical Software 67(1): 1 - 48.

[32] Kuznetsova, A., Brockhoff, P.B., Christensen, R.H.B., (2017). lmerTest Package: Tests in Linear Mixed Effects Models. Journal of Statistical Software, 82(13): 1 - 26.

[33] Deepayan, S., 2008 Lattice: Multivariate Data Visualization with R. Springer, New York. ISBN 978-0-387-75968-5

[34] Wickham, H., 2009. ggplot2: Elegant Graphics for Data Analysis. Springer-Verlag New York.

[35] Blanusa, T., Fantozzi, F., Monaci, F., Bargagli, R., 2015. Leaf trapping and retention of particles by holm oak and other common tree species in Mediterranean urban environments. Urban Forestry and Urban Greening 14: 1095 - 1101.

[36] Freer-Smith, P.H., Beckett, K.P., Taylor, G., 2005, Deposition velocities to Sorbus aria, Acer campestre, Populus deltoides x trichocarpa 'Beaupre', Pinus nigra and x Cupressocyparis leylandii for coarse, fine and ultra-fine particles in the urban environment. Environmental Pollution 133: 157-167.

[37] Garland, J.A., 1983. Some recent studies of the resuspension of deposited material from soil and grass. In Precipitation Scavenging, Dry Deposition and Resuspension (Ed.), Pruppacher, H.R., Semonin, R.G., Slinn, W.G.N., Vol 2, pp 1087 1097, Elsevier, Amsterdam.

[38] Nicholson, K.W., 1993. Wind tunnel experiments on the resuspension of particulate material. Atmospheric Environment Part A General Topics 27: 181 - 188.

[39] Hinds, W.C., 1986. Aerosol Technology. Wiley Interscience, New York.

[40] Corn, M., Stein, F., 1965. Re-entrainment of particles from a plane surface. American Industrial Hygiene Association Journal 26: $325-336$.

[41] Beckett, K.P., Freer-Smith,P., Taylor,G., 2000. Effective tree species for local air quality management. Journal of Arboriculture. 26: 12 - 19.

[42] Kardel, F., Wuyts, K., Maher, B.A., Hansard, R., Samson, R., 2011. Leaf saturation isothermal remanent magnetization (SIRM) as a proxy for particulate matter monitoring: Inter-species differences and in season variation. Atmospheric Environment. 45: 5164 -71.

[43] Chen, L., Liu, C., Zhang, L., Zou, R., Zhang, Z., 2017. Variation in tree species ability to capture and retain airborne fine particulate matter (PM2.5). Nature - Scientific Reports $1-11$.

[44] De Nicola, F., Maisto, G., Prati, M.V., Alfani, A., 2008. Leaf accumulation of trace elements and polycyclic hydrocarbons (PAHs) in Quercus ilex L. Environmental Pollution 153: 376 - 83.

[45] Postek, M.T., Vladár, A.E., 2013. Does your SEM really tell the truth? How would you know? Part I. Wiley Periodicals, Inc Scanning 35: 355 - 361.

[46] Postek, M.T., Vladár, A.E., Purushotham, K.P., 2014. Does your SEM really tell the truth? How would you know? Part 2. Wiley Periodicals, Inc. Scanning 36: 347 -355.

[47] Van Veld, R.D., Shaffner, T.J., 1971. Charging effects in scanning electron microscopy. Scanning Electron Microscopy IITRI $17-24$.

[48] Pawley, J.B., 1972. Charging artifacts in the scanning electron microscope. Scanning Electron Microscopy IITRI 153 - 160.

[49] Shaffner, T.J., Hearle, J.W.S., 1976. Recent advances in understanding specimen charging. Scanning Electron Microscopy IITRI $61-69$.

[50] Postek, M. T., Vladár, A. E., 2015. Does Your SEM Really Tell the Truth?-How Would You Know? Part 4: Charging and its Mitigation. Proceedings of SPIE The International Society for Optical Engineering 9636: 963605

[51] Robinson, V.N.E., 1980. Imaging with backscattered electrons in a scanning electron microscope. Scanning 3: 15 - 26.

[52] Burkhardt, J., 2010. Hygroscopic particles on leaves: nutrients or desiccants? Ecological Monographs Ecological Society of America 80(3):369-399. 